\title{
Start-Ups as One of the Elements Triggering the Development of Industry 4.0
}

\author{
Ryszard Pukala ${ }^{1, *}$ \\ ${ }^{1}$ Bronislaw Markiewicz State Higher School of Technology and Economics, Czarnieckiego St. 16, \\ 37-500 Jaroslaw, Poland
}

\begin{abstract}
The study analyses the significance of start-ups in the contemporary economy in the light of the industrial revolution - Industry 4.0. It presents the essence of the fourth industrial revolution and its main components that are aimed at creating intelligent value chains on the basis of dynamic, self-organising and self-optimising sociotechnical systems. Modern information and communication technologies that are increasingly integrated with production processes are used to this end. In this aspect, new digital client access channels are of key significance, as they allow departing from the traditional "push" model (pushing products into the market) and moving towards the "pull" model (production on demand). Start-ups play an important role as regards these relationships, since they operate in an ecosystem tailored to their needs and, as a result, they become more important in creating digital business models. These models, in turn, enable them to gain competitive advantage under volatile market conditions. Competition is an immanent feature of start-ups: operating under in an environment marked by high risk forces them to accept challenges that lead them to achieving market success and stable long-term development. The results of conducted analyses indicate that competition, treated as the main hazard for the operation and development of start-ups, depends on the developmental status of such enterprises and their market lifespan.
\end{abstract}

\section{Introduction}

The contemporary global economy is marked by considerable changes that take place in various sectors of the industry. We are witnessing the fourth industrial revolution, which allows linking devices into digital ecosystems as well as deepening the integration within vertical and horizontal value chains. This is favoured by a significant growth in the number of available data and of computational capacity, which in turn is a consequence of the development of information and communication technologies that are more and more integrated with the production processes. Constant evolution of these technologies triggers industrial capacity, reduction of production costs and provision of efficient solutions aimed at improving quality, increasing the speed of delivery and meeting individual needs [1]. This is also reflected in increased efficiency of managing enterprise resources, production

*Corresponding author: ryszard.pukala@interia.pl 
planning and product lifecycle. In the face of technological progress and a scenario where the demand for products tailored to individual needs, greater complexity, higher quality and lower costs is on the rise, the emergence of a new industrial model is identified as Industry 4.0 [2]. Its essence lies in the creation of intelligent value chains based on dynamic, selforganising and self-optimising sociotechnical systems, named intelligent factories. They are formed by spontaneously emerging virtual networks that cover employees, machines and devices as well as auxiliary IT systems. They constitute a dynamic value concentrated around a common cooperative object, which is subject to constant reconfiguration depending on the changes of objectives and conditions [3]. New digital client access channels, owing to which a transition from the traditional "push" model (pushing products into the market) to the "pull" model (production on demand) was possible, are of key importance in this process.

The Industry 4.0 report The new industrial revolution. How Europe will succeed by Roland Berger points out several principal features of this initiative. They include [4]: smart robots and machines; big data; new quality of connectivity; energy efficiency and decentralization; virtual industrialization.

We need to emphasize that all presented solutions intermingle and continue entering into mutual logical interactions that in a long run will probably be controlled not by a human being, but by artificial intelligence.

Contemporary enterprises further depart from the known rules of market competition in the national and international dimension and increasingly compete along the "digital enterprise" versus "analogue enterprise" line of division. The business potential of particular enterprises becomes their "to be or not to be" in the new, innovative sectors and services. Therefore, more and more enterprises start creating their own digital business models that can become a tool for achieving competitive advantage under changeable market conditions. Within the framework of Industry 4.0 enterprises see benefits that can translate into reduced costs and enhanced operational efficiency. Suffice to take a glance at selected indicators concerning the economy and enterprises - Table 1 .

Table 1. Diverse effects of Industry 4.0

\begin{tabular}{|l|c|}
\hline \multicolumn{2}{|c|}{ Effects of Industry 4.0 until 2020 } \\
\hline $\begin{array}{l}\text { Annual investments in digitalization in Poland; return on investment for } \\
\text { two-thirds of them is expected within 2 years or less }\end{array}$ & 100 bln PLN \\
\hline $\begin{array}{l}\text { The number of "Internet of Things" devices connected to the network in } \\
2021\end{array}$ & 21 bln \\
\hline $\begin{array}{l}\text { The following number of the following devices will operate within global } \\
\text { digital ecosystems: }\end{array}$ & $\begin{array}{c}\text { gas turbines - } 10 \text { thou } \\
\text { jet engines - } 68 \text { thou } \\
\text { light bulbs - } 100 \mathrm{mln} \\
\text { cars - } 152 \mathrm{mln}\end{array}$ \\
\hline Expected productivity growth in Europe & $55 \%$ \\
\hline Average increase in annual income & $2,9 \%$ \\
\hline Average decrease in operating costs per year & $3,6 \%$ \\
\hline
\end{tabular}

Source: https://napedzamyprzyszlosc.pl/raporty/gospodarka-4-0-czas-zmiany-dla-biznesu

The success of an enterprise in the reality of Industry 4.0 represents a great chance for further development. However, it also depends on clear regulations that favour innovative business models [5]. These regulations should cover enterprises and consumers and facilitate the creation of an efficient ecosystem where technological innovation and new business models emerge. If necessary, these regulations should be adjusted to new market requirements.

\section{The ecosystem of start-ups}


Industry 4.0 is characterized by a high level of economic innovation. This is not only attributable to enterprises that form it, but also to the entire business environment that shapes its support network, referred to as an ecosystem. The term ecosystem was first introduced by J.F. Moore, who stated that achieving business success requires a set of resources, such as capital, partners, suppliers and clients as part of the collaboration network, where companies can compete and cooperate in the process of creating innovative products and services as well as delivering value to clients [6]. This term refers to broadly understood entrepreneurship and entities involved in that process. According to M. Iansiti and R. Levien, the entrepreneurial ecosystem is a network of stakeholders consisting of loosely connected entities that interact in a complex way, and its capacity and efficiency depend on particular ecosystem participants [7]. Somewhat differently, M. Peltoniemi and E. Vuori perceive the ecosystem as a population of organisations that constitute a dynamic structure that consists of interlinked social organisations, small enterprises, large corporations, universities, research centres, public sector organisations and other parties that have impact on the ecosystem [8,9]. All these elements shape the field of start-ups' operation. The term can also refer to the business ecosystem, which consists of a group of enterprises and other organisations, which through interaction benefit from interdependencies to create goods, technologies and services that fall into the realm of clients' interest. The main participants of ecosystems understood as such are enterprises/products and clients, plus suppliers, competitors etc. However, the client is at the centre of attention, therefore deep understanding of the role of the client in the ecosystem is one of the challenges faced by ecosystems [10]. The business ecosystem is a place where enterprises can survive at the presence of competitors focused on gaining patronage over the available pool of clients [11].

When analysing various ecosystems, we need to stress that the ecosystem of start-ups differs from others as regards the specificity of their main components, which include [12]:

- start-ups and entrepreneurs and employees that form them,

- various categories of institutions in the start-up environment, the most important of which include business incubators, higher education institutions, research centres, entities providing legal, consulting, financial and other services as well as corporations and financing authorities,

- ideas, inventions and innovations as well as information resources,

- mentors, investors, advisers,

- resources allowing cooperation in the real (coworking) and virtual space (social communities).

The abovementioned elements create a broadly understood structure of stakeholders, who either directly or indirectly partake in the creation and development of start-ups.

Factors that have impact on the success of start-ups and at the same time represent success components within the start-up ecosystem can be divided into three categories [13]:

- internal factors that depend on the young company,

- external factors,

- availability of mentoring as part of incubators and accelerators.

All of them represent conditions that stimulate operation and development of start-ups Table 2.

Table 2. Categories of start-up success factors

\begin{tabular}{|l|l|l|}
\hline \multicolumn{1}{|c|}{ Internal factors } & External factors & $\begin{array}{c}\text { Support by incubators/ } \\
\text { accelerators }\end{array}$ \\
\hline - employees, team & $\bullet$ governmental policy & $\bullet$ mentoring \\
- work culture & $\bullet$ political stability & $\bullet$ development of links \\
c co-founders & $\bullet$ location & within the network \\
\hline
\end{tabular}




\begin{tabular}{|c|c|c|}
\hline $\begin{array}{l}\text { - ability to communicate the business } \\
\text { idea } \\
\text { - } \text { organizational structure } \\
\text { - exit strategy } \\
\text { - marketing strategy } \\
\text { - client network } \\
\text { - product } \\
\text { - scale building ability } \\
\text { - life - work balance }\end{array}$ & $\begin{array}{l}\text { - } \text { access to talents } \\
\text { - } \text { access to new } \\
\text { markets } \\
\text { - access to existing } \\
\text { - markets } \\
\text { - } \text { competition } \\
\text { previous experience }\end{array}$ & $\begin{array}{l}\text { - } \quad \text { financing } \\
\text { - } \quad \text { taxes, legal, business } \\
\text { and other aspects } \\
\text { - infrastructure } \\
\text { - } \quad \text { workshops/events }\end{array}$ \\
\hline
\end{tabular}

Taking all abovementioned categories of factors into account, we have to underline that the operation of start-ups is burdened with a high degree of risk. Therefore, in their case the ecosystem consists of entities determined to create new products and services under a high degree of uncertainty, making use of available resources and functioning in a certain regulatory environment [14].

\section{Significance and competitiveness of start-ups}

Start-ups have become an inseparable component of the economy. As shown by analyses of CBInsights, in August 2018 the total of 271 start-ups with a value of USD billion and more operated on the global market. Their total value amounted to ca. USD 869 billion. With regard to the value, Uber topped the ranking with USD 72 billion. Didi Chuxing - Uber's competitor on the Chinese market -ranked second with the value of USD 56 billion. Another Chinese company - China Internet Plus Holding (Meituan Dianping) ranked third, with the value of USD 30 billion.

Table 3. Countries with the largest number of start-ups

\begin{tabular}{|l|c|c|}
\hline \multicolumn{1}{|c|}{ Country } & Number of start-ups & Total value in USD \\
\hline USA & 126 & 438 \\
\hline China & 78 & 289 \\
\hline United Kingdom & 15 & 35 \\
\hline India & 13 & 32 \\
\hline Germany & 6 & 12 \\
\hline Israel & 4 & 5 \\
\hline South Korea & 3 & 11 \\
\hline Indonesia & 3 & 5 \\
\hline France & 2 & 2 \\
\hline South Africa & 2 & 2 \\
\hline Switzerland & 2 & 2 \\
\hline Columbia & 2 & 2 \\
\hline
\end{tabular}

Source: [15]

The highest figures are shown by Chinese and Korean start-ups - USD 3.7 billion each on average, as well as American ones, with an average value of USD 3.5 billion. However, we need to note that the country of start-up origin/registration/launch does not clearly define its operational area. The vast majority of such enterprises, through using modern data processing and client access technologies, operate in the global dimension. In this way, they gain access to a very broad market of potential recipients but also clash with competitors that often benefit from the awareness of the specificity of local markets or legal restrictions.

In the reality of contemporary global economy, competition becomes one of the most important determinants of the market position of an enterprise [16-18]. Generally, one 
could say that competition reflects the company's potential - resources, skills and abilities that guarantee gaining advantage over other entities operating in the same sector. Therefore, competition can be defined as a multidimensional feature of an enterprise, both resulting from its internal characteristics and related to the ability to adapt to changes taking place in the surroundings. This is a feature that defines a company's distinctive capacity to undertake actions that safeguard stable and long-term development and contribute to building market value. It also refers to describing mutual relations taking place between enterprises in a given sector as well as to comparing assessments of operation of selected companies $[19,20]$.

Competition is also an immanent feature of start-ups, as they must take challenges aimed at achieving market success and long-term stable development, while burdened by high risk $[21,22]$. The results of conducted analyses show that competition treated as the main hazard for the operation of start-ups depends on the developmental status of such enterprises and their market lifespan ${ }^{*}-$ Chart 1.

Chart 1. Assessment of increased competition as the main risk for start-up operation - distinction by lifespan and developmental status

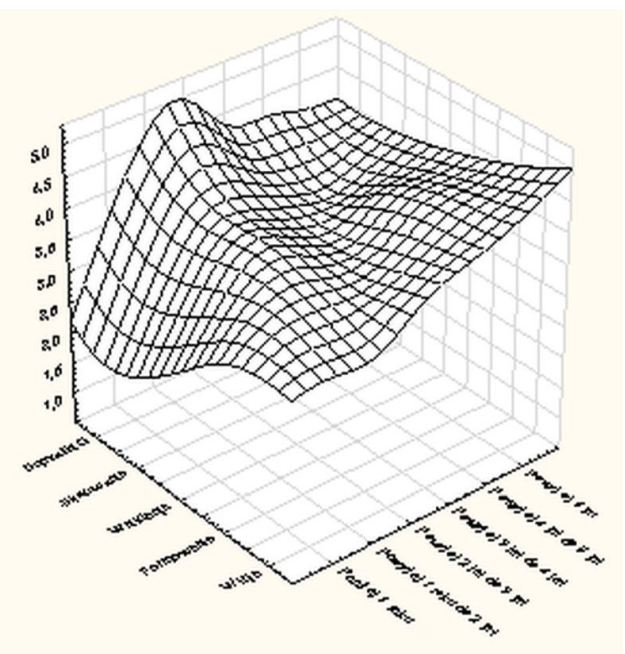

Fig. 1. Own calculations made with the aid of the Statistica software

The chart topography indicates that the impact of losing financial liquidity on the startup operation is evaluated as:

- Maximal (5 points) - by enterprises active for between 2 and 3 years, in the phase of maturity, as well as enterprises active for over 5 years, in the phase of vision. Beyond doubt, relatively young enterprises that have already reached the maturity stage still remain in the phase of intense financial investments dedicated to further development and advertising. It takes place alongside a simultaneous copying of solutions and products or services offered by competing entities, which can pose a threat for further development. When it comes to other start-ups, their long lifespan and the accompanying lack of development (vision phase) indicates that such enterprises have either failed to come up with an offer that could be competitive on the market or to

\footnotetext{
${ }^{*}$ The study was conducted among 200 start-ups in October and November 2018.

The study assumed that we can distinguish five stages in the lifespan of start-ups: vision, forming, validation, scaling and maturity; the lifespan included the following ranges: up to 1 year, between 1 and 2 years, between 2 and 3 years, between 3 and 4 years, between 4 and 5 years and over 5 years; the adopted risk assessment scale: from 1 (the lowest impact) to 5 (the highest impact).
} 
amass funds for further development. In both cases time works for their disadvantage and it is hard to expect that such start-ups will achieve market success.

- High (4 points) - by representatives of start-ups operating for over 3 years and remaining in the formation, validation, scaling and maturity phases. When it comes to start-ups in the formation and validity phases, we can talk mainly about difficulties with refining the product, too long a testing time and shrinking funds, which can pose a threat for the enterprise operation. As regards entities in the scaling and maturity phase, insufficient funds and loss of market advantage due to the "ageing" of the start-up offer make up important factors that can inhibit their development.

- Average (3 points) and below average - by representatives of start-ups operating for up to 2 years and remaining in the validation, scaling and maturity phase. In this case we can talk about a very dynamic development of an enterprise, which in a relatively short time wins its position on the market, followed by competitive advantage gained.

Each start-up's determination to reach product scalability and maturity in a relatively short time ensues taking actions aimed at gaining competitive advantage. Increasing revenue streams from executed production can help in this process. Beyond doubt, this is a chance for continuing dynamic growth and achieving market success, which is exactly what every enterprise aspires to.

\section{Conclusions}

The driving force behind Industry 4.0 is a conviction that enterprises that efficiently implement their developed solutions can count on the increased revenues and get an impulse for further dynamic development. Enterprises that have already undergone digital transformation, which is definitely the case with start-ups, will most probably achieve better results on the market, take leading positions and set directions for further development. The direction of changes in value chains concerning products and services that are subject to strong integration processes will be determined by client needs. Such entities will be better adapted to their individual needs, which is going to made possible by data analytics and application of innovative solutions aimed at personalisation of the offer. Start-ups operating as part of Industry 4.0 play an ever more important role in the process of creating and implementing innovative solutions. Their market success is reflected in a dynamically growing value and importance when it comes to offering their products and services to an increasing group of recipients all around the world. When striving to reach maturity and market success, start-ups encounter the problem of increasing competition that can pose a threat for their development or even lead to their insolvency. However, broad use of Industry 4.0 components by such enterprises and their sustainable growth, taking account on the one hand of high operating risk and on the other hand of chances and possibilities of development created by the market, enable start-ups to gain more and more importance in the contemporary economy.

\section{Reference}

1. C. Cheng C., T. Guelfirat, C. Messinger, J. Schmitt, M. Schnelte and P. Weber, 10th Joint Meeting on Foundations of Software Engineering (ESEC/FSE 15), 1010 (2015)

2. M. Hermann, T. Pentek and B. Otto, Proc. 49th Hawaii International Conference on System Sciences (HICSS), 3928 (2016)

3. J. Bendkowski, Zmiany $w$ pracy produkcyjnej $w$ perspektywie koncepcji (Seria: Organizacja I Zarządzanie, 1990)

4. R. Pukala, Engineering Management in Production and Services, 8:3, 43 (2016) 
5. J. F. Moore, Harvard business review, 71:3, 75 (1993)

6. M. Iansiti, R. Levien, Harvard Business Review, 3:82, 68 (2004)

7. M. Peltoniemi, E. Vuori, Proceeding of the Complexity, Science and Society Conference, (2005)

8. R. Pukala, E. Sira, R.Vavrek, Marketing and Management of Innovations, 3, 153 (2018)

9. S.A. Zahra, S. Nambisan, Business Horizons, 55, 219 (2012)

10. M.M. Mars, J.L. Bronstein, R.F. Lusch, Organizational Dynamics, 41, 271 (2012)

11. Grow Advisors, The start-up Ecosystem White Paper (2018)

12. J. Olszyński, E. Sońta-Drączkowska, Oficyna Wydawnicza Szkoły Głównej Handlowej w Warszawie, 4 (2017)

13. Diagnoza ekosystemu start-upów w Polsce, Raport Deloitte Polska, (2016)

14. M. Petrova, M. Tepavicharova, Lyudmila Boykova. E3S Web of Conferences, 41, 04017, (2018)

15. N. Kurmanov, B. Tolysbayev, D. Aibossynova, N.Parmanov, Economic Annals-XXI, 158, 57 (2016)

16. Sv. Labunska, M. Petrova, O. Prokopishyna, Economic Annals - XXI, 165:5-6,13 (2017).

17. M. Gorynia Wydawnictwo Akademii Ekonomicznej w Poznaniu, Poznań, 48 (2002)

18. M. Petrova, N. Dekhtyar, O. Klok and O. Loseva, Problems and Perspectives in Management, 16:4, 259 (2018)

19. N. Kurmanov, B. Beisengaliyev, A. Dogalov, D. Turekulova, N. Kurmankulova, International Journal of Economics and Financial, 4, 1440 (2016)

20. N. Kurmanov, D. Turekulova, G. Doskeyeva, G. Alina, The case of Kazakhstan. International Journal of Economics and Financial Issues, 6:3, 907 (2016) 